\title{
Changes in Mesopotamian Wetlands: Investigations Using Diverse Remote Sensing Datasets
}

\author{
Ali K. M. Al-Nasrawi \\ University of Wollongong \\ Ignacio Fuentes ( $\nabla$ ignacio.fuentes@sydney.edu.au ) \\ The University of Sydney https://orcid.org/0000-0001-7066-7482 \\ Dhahi Al-Shammari
}

The University of Sydney

\section{Research Article}

Keywords: Ecosystem disturbance, remote sensing, wetlands, marshes, ancient civilizations

Posted Date: February 8th, 2021

DOl: https://doi.org/10.21203/rs.3.rs-165486/v1

License: (1) This work is licensed under a Creative Commons Attribution 4.0 International License.

Read Full License 


\section{Changes in Mesopotamian wetlands: Investigations using diverse remote sensing}

2 datasets

$4 \quad{ }^{a}$ School of Earth, Atmospheric and Life Science, University of Wollongong, Wollongong NSW 2522,

5 Australia.

$6 \quad{ }^{b}$ School of Life and Environmental Sciences, University of Sydney, Sydney NSW 2000, Australia

$7 \quad{ }^{\mathrm{c}}$ Department of Geography, University of Babylon, Ministry of Higher Education and Scientific

8 Research, Hillah - Babylon, Iraq

Corresponding author: Ignacio Fuentes (ignacio.fuentes@sydney.edu.au)

\section{Abstract}

13 Early civilizations have inhabited stable-water-resourced areas that supported living needs and activities,

14 including agriculture. The Mesopotamian marshes, recognised as the most ancient human-inhabited area

15 ( 6000 years ago) and refuge of rich biodiversity, have experienced dramatic changes during the past five

16 decades, starting to fail in providing adequate environmental functioning and support of social communities

17 as they used to for thousands of years. The aim of this study is to observe, analyse and report the extent of

18 changes in these marshes from 1972 to 2020. Data from various remote sensing sources were acquired

19 through Google Earth Engine (GEE) including climate variables, land cover, surface reflectance, and

20 surface water occurrence collections. Results show a clear wetlands dynamism over time and a significant

21 loss in marshlands extent, even though no significant long-term change was observed in lumped rainfall

22 from 1982, and even during periods where no meteorological drought had been recorded. Human 
23 interventions have disturbed the ecosystems, which is evident when studying water occurrence changes.

24 These show that the diversion of rivers and the building of a new drainage system caused the migration and

25 spatiotemporal changes of marshlands. Nonetheless, restoration plans (after 2003) and strong wet

26 conditions (period 2018 - 2020) have helped to recover the ecosystems, these have not led the marshlands

27 to regain their former extent. Further studies should pay more attention to the drainage network within the

28 study area as well as the neighboring regions and their impact on the streamflow that feeds the study area.

29 Keywords

30 Ecosystem disturbance, remote sensing, wetlands, marshes, ancient civilizations

32 Declarations

\section{Funding}

All funding sources were mentioned in the Acknowledgements section

Conflicts of interest

Authors declare no conflict of interests

Availability of data and material

All datasets used are publicly available.

\section{Authors' contributions}

The original conception of the study was developed by A.K.M.A.N. All authors contributed to the study design. Material preparation, data collection and analysis were performed by I.F. and D.A.S. manuscript. 
45 Most geological studies evince that the Earth was first shaped and stabilised about 4.5 billion years ago

46 (Halverson et al. 2009). However, the Earth has recently become liveable for the first life-species existence

47 on earth, which have geologically been proven just after the Cretaceous ended $\sim 65$ million years ago

48 (Purves et al. 2013; Kolbert 2014). Moreover, anthropological literature shows that the first Homo sapiens

49 only evolved on Earth just before 300,000 (Hamilton 2017; Brauer and Smith 2020). Until about 12,000

50 years ago (during the Neolithic Revolution) humans mainly lived as hunters and gatherers, usually in small

51 communities like family groups (Lee et al. 1999). Then about 6000 years later, their lifestyle started to

52 change, and humans started gathering in larger communities, inhabiting the resources-rich riverine

53 environments, and establishing a way of securing their survival by building the first civilizations (Meyer

54 1959; Putong 2013). The first four recognised civilizations were established in (1) Mesopotamia $-\sim 6000$

55 years ago (Tigris and Euphrates Rivers), (2) Egypt - 5100 years ago (Nile River), (3) the Indus valley -

56 4500 years ago, and (4) China - 3600 years ago (Yangtze and Yellow Rivers) (O’Regan 2008; Robson

57 2020). The Mesopotamian civilization (as the focus of this study) is the most ancient and formed on the

58 banks of the Tigris and Euphrates Rivers $~ 6000$ years ago (Potts 1997). Evidence through the consecutive

59 societies in this area, including Sumerian, Assyrian, Akkadian and Babylonian (George 2002), shows

60 extensive use of technology, literature, legal codes, philosophy, religion, and architecture (Trigger 2003).

61 Sumerians were the first to inhabit the flood plain of the lower reaches of the Tigris and Euphrates Rivers,

62 where the riverine delta consists of many infilled lagoons and wetlands that are locally known as

63 Mesopotamian marshes (Banister 1980). These marshes are the primary focus of this paper.

64 Wetlands play important roles in integrating the natural environment (Mitsch and Gosselink 1993). Without

65 a doubt, they are invaluable ecosystems, as they reduce flood impacts, enhance water quality by absorbing

66 pollutants, and serve as important faunal habitats among many other environmental, recreational, and

67 economic advantages (Al-Nasrawi 2018). In fact, wetlands were not only a kind of fancy option for early

68 communities, but they were also the essential key for early civilization development (Maltby and Acreman 

concentrated around the lower reaches where wetlands occurred (Maisels 2001). These ecosystems

71 provided such a rich environment that they played an essential role in people's lives and development

72 (Maisels 2001). These prosperous environments resulted from the stability of water and food resources,

73 combined with diverse habitats that could not be found anywhere else (Trigger 1993). Wetlands also

74 provided early settlers with inhabitable environments characterized by easy access to necessary resources

75 and favourable weather conditions. These circumstances facilitated the transformation and development of 76 their communities, technology and ultimately their entire cultures. Innovations and advancements included 77 the implementation of irrigation systems and the invention of the wheel, plow and cuneiform writing 78 (Faiella 2006). Therefore, natural wetlands in general, and particularly the Mesopotamian marshes, have 79 played a pivotal role in human life development for more than 6000 years (Faiella, 2006). However, the 80 environmentally unsustainable development during the industrial revolution, especially in the twentieth 81 century, has severely impacted these ecosystems (Chew 1999; Al-Nasrawi et al. 2018). The Mesopotamian 82 wetlands were significantly damaged at all levels over the past $\sim 50$ years by rapid environmental alterations 83 (Richardson et al. 2005), resulting in a collapsed ecosystem, severe droughts, economic distraction, and $84 \quad$ ultimately the forced migration of several million people out of the area.

Under these circumstances, the fundamental question now is: What specifically caused the rapid collapse of these ecosystems, which have been so crucial to the development of human civilizations, after

87 accommodating them for 6000 years? Thus, this research is trying to provide answers as to the reasons for this environmental catastrophe.

\section{Current stressors and efforts in the region}

90 Human development, with its exponential increase of fossil fuel use and greenhouse gas production over 91 the last $\sim 200$ years, is the principal cause of climate change, which is seriously influencing ecosystems 92 worldwide (Harley et al. 2012). In the Mesopotamian region, droughts are the most devastating manifestation of this trend, with low precipitation and elevated temperatures having the strongest impact 
on the ecosystems (Senapati et al. 2019). Additionally, human interventions such as water discharge regulation and the implementation of artificial drainage systems enhance these pressures by further degrading and damaging the wetland ecosystems (Al-Nasrawi et al. 2016).

97 The water issue has always been a bottleneck that restricted the development of the Middle East (Allan 98 2012). The Mesopotamian marshlands in southern Iraq and across the Iranian border (Figure 1) are the 99 largest wetlands and among the most populous in the region, but they have been increasingly faced with water shortage and crises throughout the last decade (Madani 2014). Mesopotamian wetlands, nowadays, are limited to southeastern Iraq and extend across the western Iranian border (Al-Zaidy et al. 2019;

102 Sissakian et al. 2020).

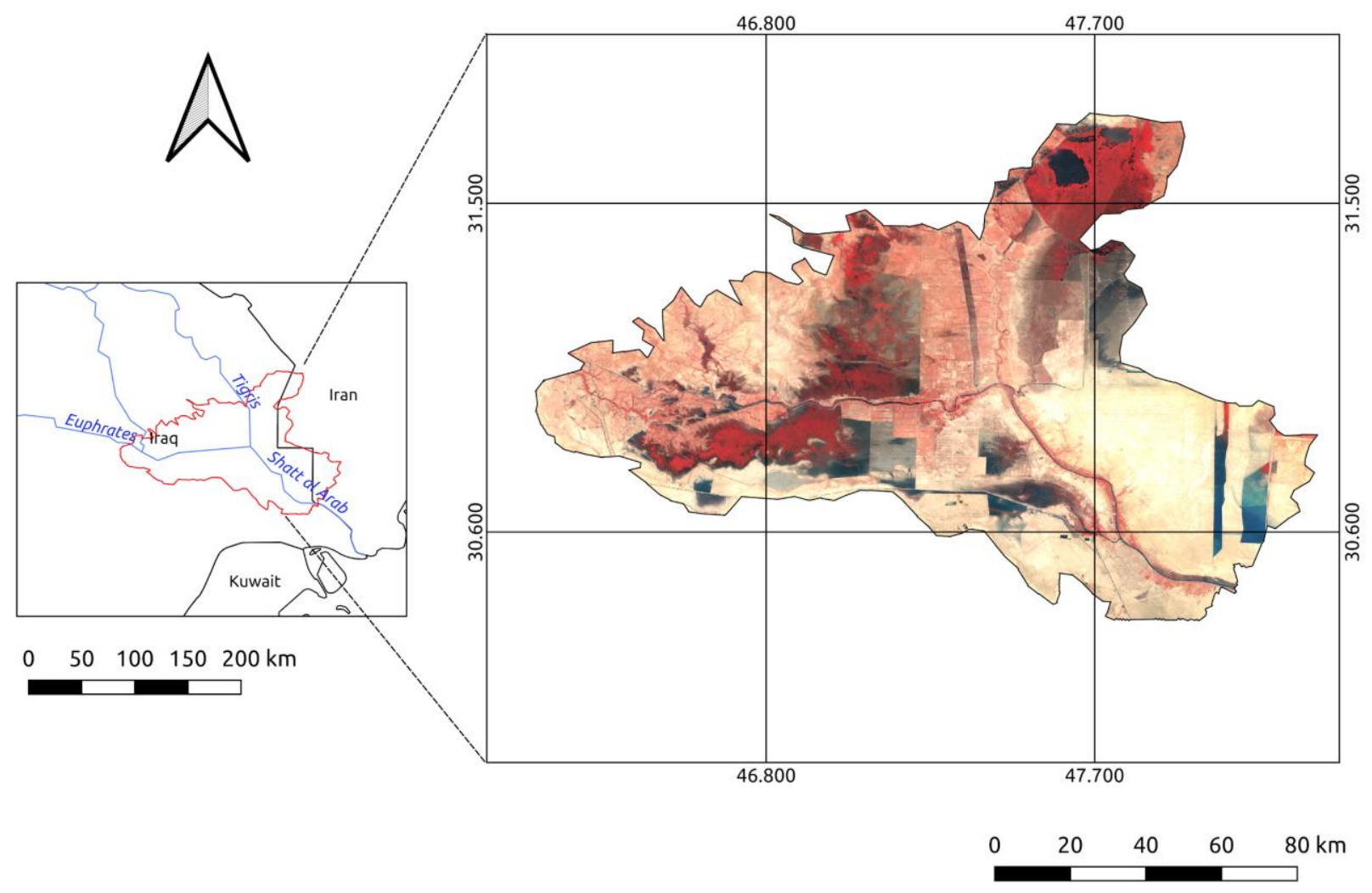

Figure 1. Spatial extent of Mesopotamian marshlands, as a false colour average composite of Landsat 8 images (2013-2020), in the study area located in southern Iraq and across the western Iranian border. 
108 UNESCO has recently listed all the southern Iraq wetlands (Supplementary 1) as a "World Heritage Site" 109 known as Mesopotamia or the Garden of Eden (UNESCO-World Heritage Centre 2016). On the Iranian 110 side, of the 44 internationally known wetlands (Najaf and Vatanfada 2011), 24 of them are on the Ramsar 111 Convention wetland list (Davidson et al. 2019; Hamman et al. 2019). Many of these wetlands in both 112 countries and all over the Middle East are seriously damaged due to the negative effects of climate change 113 and various human activities (Naddafi et al. 2005; Zamani-Ahmadmahmoodi et al. 2009). Some of them 114 have even been destroyed, while historically they served as popular safe habitats for many endangered 115 species, including migratory birds (Abed 2007).

116 Conservation activities that have been carried out so far have not prevented the alteration and destruction 117 of wetlands or reduced the damage due to their dispersal and inefficiencies (Hamzeh et al. 2017). Iraq and 118 Iran made tackling their water crises national priorities but the lack of technical know-how and funding, 119 and the difficulty of cooperating regionally and internationally, has prevented significant improvements. 120 Therefore, it is crucial to put serious efforts into detecting the emerging water problems before they become 121 too costly to resolve. However, the current level of knowledge about precise monitoring and assessment of 122 water variation and land cover changes is still low and not good enough at regional and basin scales. In this 123 regard, the use of Satellite Earth Observation (SEO) applications within innovative geo-spatial analysis is 124 a key tool and unique information source to support the environmental community in various application 125 domains, including wetlands conservation and management. More specifically, existing and future SEO 126 technology can play a key role in obtaining suitable information to support the mapping and inventory of 127 wetlands as a basis for management-oriented assessment and monitoring.

128 This study aims to investigate temporal changes in the ancient Mesopotamian wetlands in southern Iraq 129 since the 1970s, using satellite imagery. These marshlands are the largest wetlands in western Asia and the 130 Middle East with unique ecosystems on the margin of a desert region. The results of this study will help to 131 describe past environmental changes in the area, will point to their socio-economic effects and will 132 ultimately provide a basis to address these changes. 
134 In this study, satellite imagery was used to detect spatio-temporal changes in the land cover dynamics of 135 the Mesopotamian region during the last few decades. The Google Earth Engine (GEE) platform 136 (Supplementary 2) (Gorelick et al. 2017) was used to access and preprocess the satellite data. GEE provides 137 the tools to access, process and analyse many images in the virtual cloud.

\section{Study area}

139 The ancient Mesopotamian marshlands (Garden of Eden) lie within the alluvial plain of the Tigris and 140 Euphrates Rivers, which are in southern Iraq and the bordering portion of western Iran (Kohl and Lyonnet 1826; Frankfort 1950; Abdulnaby et al. 2020). These two riverine sources supply the freshwater marshlands that have an average depth of $3 \mathrm{~m}$. These marshlands cover an area of about 20,000 $\mathrm{km}^{2}$ with central coordinates of $\left(31^{\circ} 02^{\prime} 04.3^{\prime \prime} \mathrm{N} 47^{\circ} 04^{\prime} 59.2^{\prime \prime} \mathrm{E}\right)$ (Abusch 2020). The marshes represent a natural phenomenon of low-lying land, which is characterised by seasonal fluctuations in water levels. Therefore, delineation of the study area boundaries is difficult. In this study, the boundary of the study area was defined "naturally" by using the 5 m elevation-contour line, which has included $15,403.65 \mathrm{~km}^{2}$ of the marshlands. This contour

147 includes most of the permanent Mesopotamia' marshes. The two ancient rivers (Tigris and Euphrates) divide these marshlands into three main permanent sections, surrounded by seasonal subsections and lakes. Hawizeh Marshes are located to the east of the Tigris, and the Hammar Marshes occur just south of Euphrates, whereas the Central section (including Al-Chibayish Marshes) lies between the Tigris and Euphrates Rivers. Together they make up the largest marsh ecosystem in the Middle East and Eurasia 152 (Pollock and Susan 1999). The study area is covered with fine to very-fine clay and silty soils (Jotheri et al. 153 2018). The climate of the Tigris/Euphrates marshes is semi-arid with a warm-dry summer (average $\sim 43^{\circ} \mathrm{C}$ ) 154 and a cold-wet winter (average $\sim 11^{\circ} \mathrm{C}$, plus $\sim 100-170 \mathrm{~mm} / \mathrm{y}$ of rain) (Shubbar et al. 2017). These unique 155 marshlands have been severely drained and subject to eutrophication since the 1990s, because of human 156 activities including the war during the 1980s. However, after 2003, restoration plans were formally 157 legislated, and laws were enacted to control water management (Al-Ansari et al. 2012). 
159 Datasets used

160 Diverse sources of data were used in this study. Monthly rainfall, lumped at the study area scale, was

161 obtained from the Famine Early Warning Systems Network (FEWS NET) Land Data Assimilation System

162 (FLDAS; McNally et al. 2017), which aggregates and processes rainfall data from the Climate Hazards

163 Group InfraRed Precipitation with Station (CHIRPS) data. Monthly accumulated daily rainfall data from

164 CHIRPS, forcing FLDAS incoming shortwave radiation and monthly ERA-5 temperatures, surface 165 pressure and wind components were also utilised. The Land Cover Type 1 from the Annual International 166 Geosphere-Biosphere Programme (IGBP) contained in the MODIS Land Cover dataset (MCD12Q1 version 167 6) was used to evaluate changes in land cover from 2001 to 2019 . This product is derived from a supervised 168 classification on MODIS surface reflectance data and post-processing using ancillary data to improve its 169 quality (Sulla-Menashe and Friedl 2018). Since this collection is based on MODIS data, its time period of 170 application is limited to the operation period of the sensors. The Joint Research Centre (JRC) Global Surface

171 Water Mapping Layers, v1.0 dataset, was also used. This dataset provides maps for water detection using 172 Landsat 5, 7 and 8 which were collected from 1984-2015 (Pekel et al. 2016) and has been considered as 173 one of the state-of-the-art products for water detection. This is based on a classification performed on each 174 pixel of the Landsat collection using an expert system. Furthermore, a water transition map was derived 175 from the JRC dataset to characterize types of changes caused by drought events and human intervention. 176 Lastly, surface water trends were derived from the Monthly Water History v1.2 dataset from the JRC (Pekel 177 et al. 2016). Lastly, tier 1 images from the Landsat 5, 7 and 8 collections were merged and used for NDVI 178 time series analysis. Landsat 1 tier 2 (Landsat 1 tier 1 data are not available for the study area) also was 179 used to extract the NDVI in the 1970s period. During the 1970s, there were several scenes available for the 180 study area. However, all these scenes are heavily contaminated with clouds or shifted from their actual 181 locations. Therefore, there were only three images that entirely cover the study area, which were cloud-free 182 and accurately positioned and were acquired between 01-08-1972 and 02-08-1972. 
The Standardised Precipitation Index (SPI) and the Standardised Precipitation Evapotranspiration Index

187 in Guenang and Kamga (2014) through a standardisation of the data using the gamma distribution:

$$
g(x)=\frac{1}{\beta^{\alpha} \Gamma(\alpha)} X^{\alpha-1} e^{-x / \beta} \text { for } x>0
$$

189 in which the shape and scale parameters are calculated as:

$190 \alpha=\frac{1}{4 A}\left(1+\sqrt{1+\frac{4 A}{3}}\right)$

$191 \beta=\frac{\bar{x}}{\alpha}$

192 being $A$ :

$A=\ln (\bar{x})-n^{-1} \sum \ln (x)$

194 where $\mathrm{x}$ corresponds to rainfall or rainfall minus evapotranspiration observations for SPI and SPEI, respectively. Subsequently, we used the incomplete gamma function (equation 5) by which the cumulative probability $G(x)$ of an observed quantity of rainfall/rainfall-evapotranspiration can be estimated:

$197 \quad G(x)=\frac{1}{\Gamma(\alpha)} \int_{0}^{x} t^{\alpha-1} e^{-1} d t$

where $t$ is $x / \beta$. Since the gamma distribution is undefined for $x=0$, positive cumulative probabilities assume the following formulae:

$H(x)=q+(1-q) G(x)$

201 being $q$ equal to $\mathrm{P}(x=0)$. Finally, the cumulative probabilities are transformed to the standard normal of $\mu$ $202=0$ and $\sigma=1$ using Eq 7:

$\operatorname{Pr}(X \leq x)=F(x)=\frac{1}{2}\left[1+\operatorname{erf}\left(\frac{x-\mu}{\sigma \sqrt{2}}\right)\right]$

204 For SPEI, where the analysis is calculated on the time series of the difference between rainfall and 205 evapotranspiration, an offset was added to the time series in order to preclude negative values, which makes the standardisation undefined. 
208 Monteith equation (Allen et al., 1998):

$209 E T_{r}=\frac{0.408 \Delta\left(R_{n}-G\right)+\gamma \frac{C_{n}}{T+273} u_{2}\left(e_{s}-e_{a}\right)}{\Delta+\gamma\left(1+C_{d} u_{2}\right)}$

210 where $\Delta$ is the saturation vapor pressure-temperature slope, $R_{n}$ the net radiation, $G$ the soil heat flux, $Y$ the

211 psychrometric constant, $T$ the mean daily temperature, $u_{2}$ the mean wind speed at $2 \mathrm{~m}, e_{s}$ the saturation

212 vapor pressure, $e_{a}$ the actual pressure vapor, and $C_{d}$ and $C_{n}$ are constants equivalent to 0.34 and 900 ,

213 respectively, being $E T_{r}$ the reference evapotranspiration.

214 The SPI and SPEI calculated were averaged to the study region and evaluated using 1-, 3-, 6- and 12-month

215 lags. This allowed us to obtain meteorological drought/wet severity classes based on Table 1.

217 Table 1. Drought/wet severity classes determined by SPI and SPEI

\begin{tabular}{ccc}
\hline \multicolumn{1}{c}{ SPI } & \multicolumn{2}{c}{ SPEI } \\
\hline Severity classes & $\leq-2$ & $\leq-2$ \\
extreme drought & $-1.9--1.5$ & $-1.9--1.5$ \\
severe drought & $-1.4--1$ & $-1.4--1$ \\
moderate drought & $-0.9-0$ & $-0.9-0$ \\
mild drought & $0-0.9$ & $0-0.9$ \\
mild wet & $1-1.4$ & $1-1.4$ \\
moderately wet & $1.5-1.9$ & $1.5-1.9$ \\
severely wet & $\geq 2$ & $\geq 2$ \\
extremely wet & & \\
\hline
\end{tabular}


221 The Monthly Water History dataset from the JRC was processed to obtain maps of annual water occurrence.

222 These were estimated at each pixel by summing the times that water occurred in the year and dividing it by

223 the times that the same pixel occurred in the year, leading to values between 0 and 1 corresponding to the

224 occurrence probability. Empty records in the annual occurrence maps were linearly interpolated, especially

225 for 1988, 1989, 1990, 1996 and 1997, assuming a smooth transition between years. The interpolated maps

226 were mosaicked with the annual occurrence maps to fill empty pixels.

227 Additionally, surface water occurrence rasters were split into three different pixel classes: (i) episodic water 228 pixels, which presented a water occurrence lower than 0.25 , meaning that water occurred in one fourth of 229 the images of the year; (ii) seasonal water pixels, which present a water occurrence between 0.25 and 0.75 , meaning that water is present seasonally in more than one quarter and less than three quarters of the annual images; and (iii) permanent water pixels with an occurrence of water greater than 0.75 , implying that surface water is present in more than three quarters of the images (Fuentes et al. 2020). Pixels from these three classes were summed to calculate the extent of their occurrence. Average water occurrence extent was also calculated as a multiplication of surface occurrence by the pixel area and lumped at the scale of the study region (mean area flooded in the study region).

\section{Trend analysis}

The land cover rasters and the estimated water occurrence collection were analysed in order to detect temporal changes. Therefore, annual maps were processed through trend analysis tests. In this case, nonparametric tests were used including the Mann Kendall test and the Sen's slope, which estimates the median

241 slope of all pairs of points. Both methods are robust and allow relaxation of some of the requirements for

242 linear trend analysis, such as the normality and homogeneity of residuals. The significance of the tests was 243 also reported to detect significant trends ( $p$-value $<0.05$ ). Additionally, for those datasets with less than 30 244 records, such as the land cover rasters obtained from the MCD12Q1 dataset, a pre-whitening of the Mann 245 Kendall test was also applied (Bayazit and Önöz 2007). 


\section{Vegetation evaluation}

248 Above-ground biomass maps were derived by estimating the Normalized Difference Vegetation Index 249 (NDVI) from the Landsat merged collection. Surface reflectance bands from Landsat were cleaned to 250 remove clouds and cloud shadows using the CFMask algorithm (Foga et al. 2017) and the Near-Infrared 251 and red bands were used to calculate the NDVI. Then NDVI was estimated as the ratio between the 252 difference in reflectance between the near infrared and red wavelengths and the sum of the reflectance at 253 these two wavelengths, to capture the amount of change in the vegetation cover due to drainage/reflooding 254 periods. Eight images of NDVI were calculated where each NDVI image represents a mean of five years 255 (except the NDVI in 1972 which was calculated from images in August only) starting from 1972 to 2020 256 to allow monitoring of medium-term vegetation change detection. These images were used to quantify the 257 changes that occurred since 1972. Since NDVI responds in a particular way to different land cover classes 258 (DeFries and Townshend 2007), a range of values between 0 and 0.2 was assumed to categorise bare soil, 259 and a range between 0.3 and 1 was used for vegetation.

\section{Results}

262 While a strong seasonal pattern in rainfall can be observed at the monthly scale (Figure 2a), with a lumped 263 intra-annual rainfall pattern ranging from around $0 \mathrm{~m}^{3}$ to about $4 \times 10^{8} \mathrm{~m}^{3}$, no trend could be observed in its 264 signal for the study period, which can be additionally inferred from the annual rainfall barplot (Figure 2b). 265 However, some extreme rainy months can also be observed, in which monthly lumped rainfall has reached 266 almost $8 \times 10^{8} \mathrm{~m}^{3}$. 


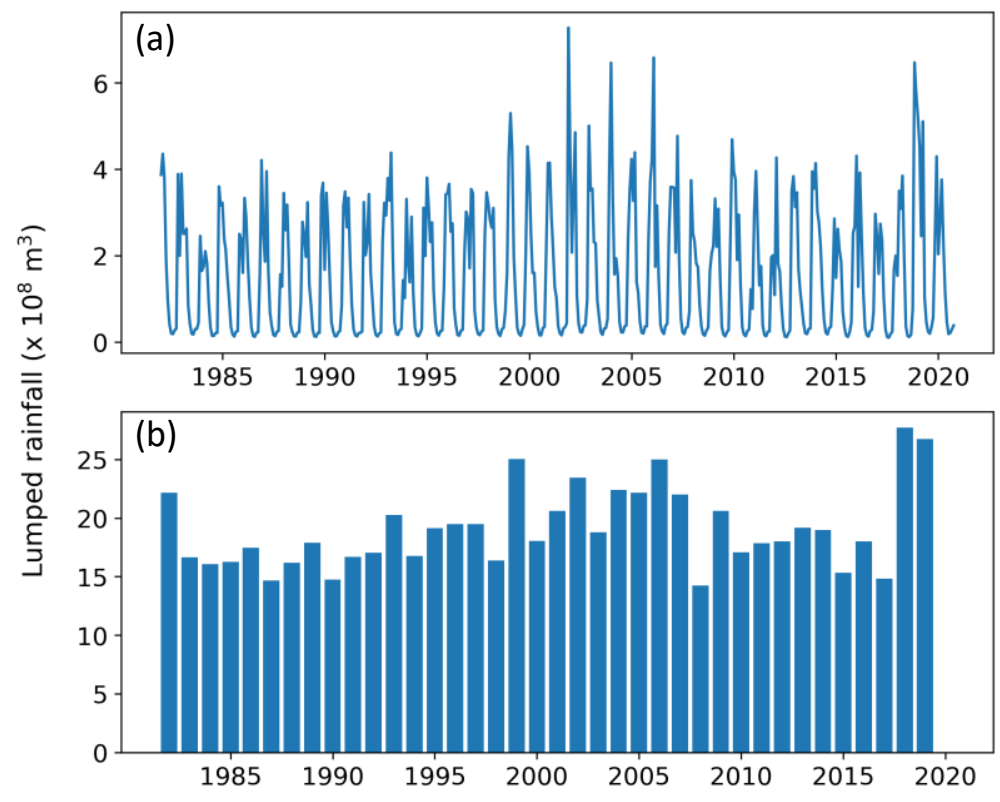

Figure 2. Lumped rainfall in the study region on (a) a monthly basis and (b) annually aggregated.

Series of SPI and SPEI are presented in Figure 3. While SPI shows a clear dominance of dry scenarios in the 1983 - 1995 and 2008 - 2018 period, these are reduced in duration in the SPEI series. On the contrary, SPI

271 shows that the 1995 - 2008 and 2018 - 2020 periods are dominated by wet scenarios in terms of rainfall.

272 In most cases, the duration of such dry - wet conditions reduces when evapotranspiration is considered.

273 Highlights in the last period, 2018 - 2020, the severity of the wet conditions, which can be observed in 274 both indices, which is also evident from the lumped rainfall.
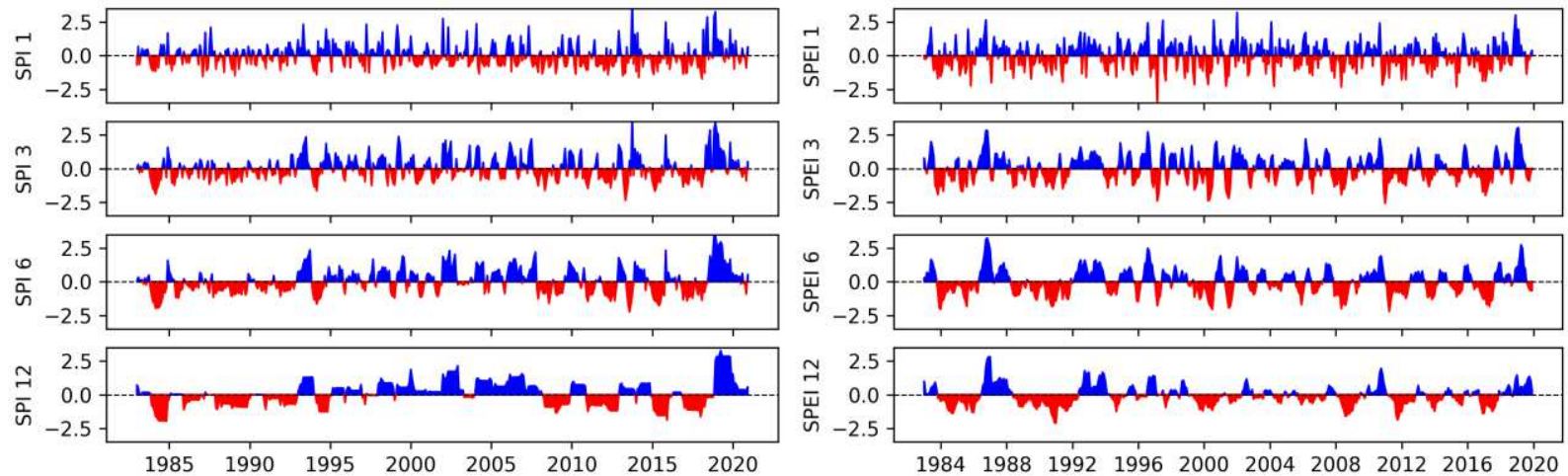

Figure 3. Average regional SPI (left) and SPEI (right) series using 1-, 3-, 6- and 12-month lags. 


\section{Land cover changes}

279 Land cover trends in terms of surface extent are presented in Table 2. Overall, strong evidence of land cover

280 changes has been registered, especially in the extent of wetland, urban and water areas. In these cases, a

281 trend is evident using both the Mann Kendall and the pre-whitened Mann Kendall methodologies. These

282 land cover classes imply changes in extent since 2001.

284 Table 2. Land cover change trends for the study area between 2001 and 2019 using Mann Kendall and

285 Sen's slope non-parametric tests and using a pre-whitening of the data.

\begin{tabular}{|c|c|c|c|c|c|c|}
\hline Land cover & $\begin{array}{l}\text { Mann Kendall Z } \\
\text { score }\end{array}$ & $\begin{array}{l}\text { Sen's slope } \\
\left(\mathrm{km}^{2} \mathrm{y}^{-1}\right)\end{array}$ & $\mathrm{p}$-value & $\begin{array}{l}\text { Pre-whitening } \\
\text { Mann Kendall Z } \\
\text { score }\end{array}$ & $\begin{array}{l}\text { Pre-whitening } \\
\text { Sen's slope }\left(\mathrm{km}^{2}\right. \\
\left.\mathrm{y}^{-1}\right)\end{array}$ & $\begin{array}{l}\text { Pre- } \\
\text { whitening } \\
\text { p-value }\end{array}$ \\
\hline Grasslands & 2.66 & 24.10 & $7.84 \mathrm{e}-03$ & $-*$ & - & - \\
\hline Wetlands & 3.56 & 26.29 & $3.59 \mathrm{e}-04$ & 2.88 & 20.94 & $3.99 e-03$ \\
\hline Urban & 5.79 & 0.54 & $6.92 \mathrm{e}-09$ & 4.36 & 0.15 & $1.30 \mathrm{e}-05$ \\
\hline Barren & 3.01 & -55.06 & $2.62 \mathrm{e}-03$ & - & - & - \\
\hline Water & 3.36 & 13.38 & $7.83 e-04$ & 2.35 & 8.79 & $1.88 \mathrm{e}-02$ \\
\hline
\end{tabular}

*Non-significant trends obtained (p-value > 0.05).

288 The results Based on the most conservative approach (pre-whitening MK) are showing that, while urban 289 areas have grown at a small trend of $0.15 \mathrm{~km}^{2} \mathrm{y}^{-1}$ in the most conservative trend estimation (15 hectares per 290 year), wetlands and water extents present much larger change rates $\left(20.94 \mathrm{~km}^{2} \mathrm{y}^{-1}\right.$ and $8.79 \mathrm{~km}^{2} \mathrm{y}^{-1}$, 

nor their reason.

Surface water dynamics

The different lumped water fraction extents and the mean surface water extent derived from Landsat images between 1986 and 2019 are presented in Figure 4.
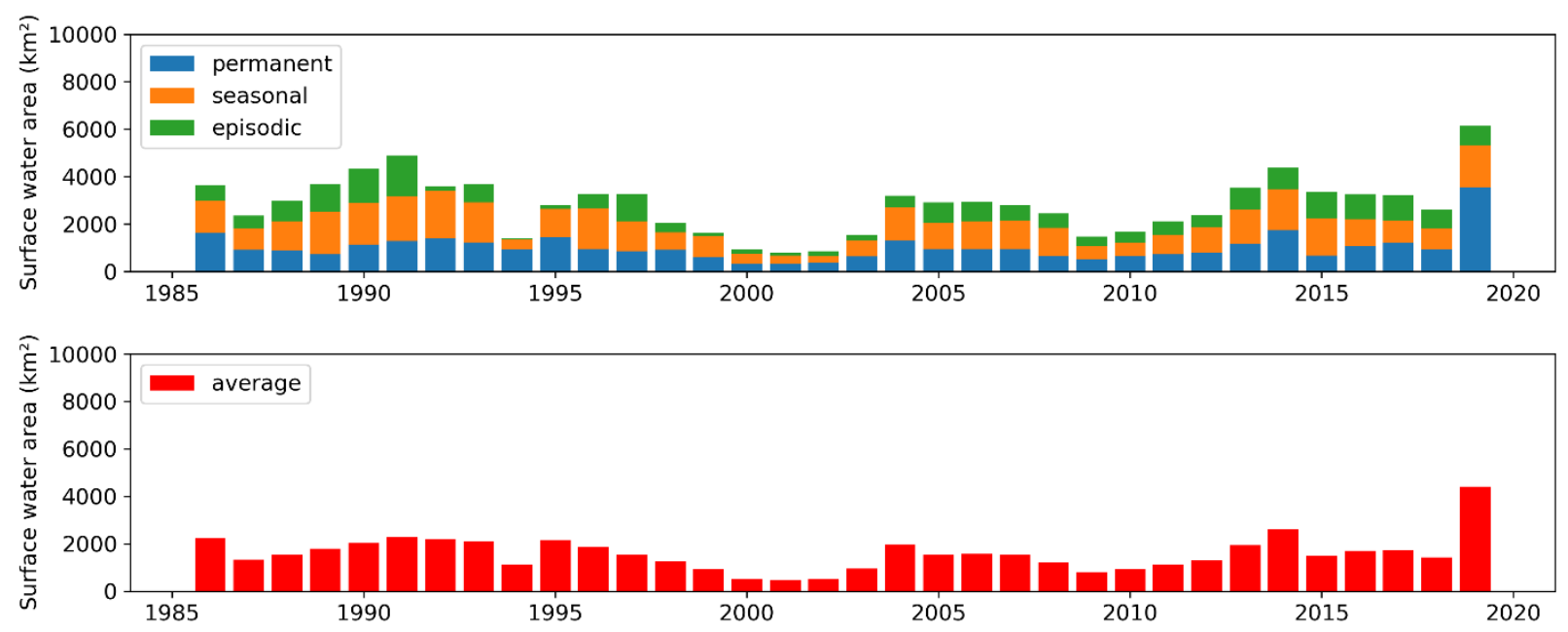

Figure 4. Annual time series of surface water fractions and average surface water extents in the study region.

301 A seasonal oscillation of surface water extent is present in the area, which is evident in cycles of wet and

302 dry years, which may be a response to interannual climate variability. The different surface water fractions 303 split quite evenly. It highlights the year 2019 for presenting the largest extent of surface water, and the years 304 1998-2003 for being the driest in the study period. Even though no trend was found in the surface water 305 fractions when lumped at the regional scale, large and significant local changes are evident in Figure 5. 


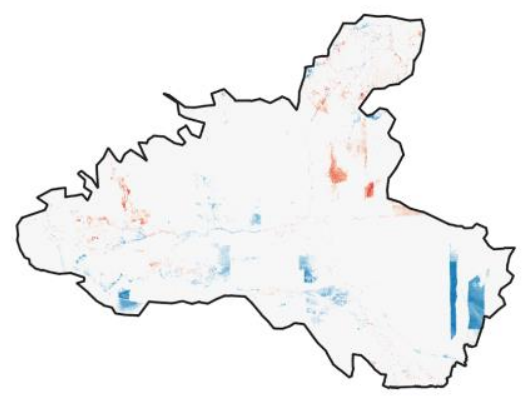

Sens's slope water occurrence
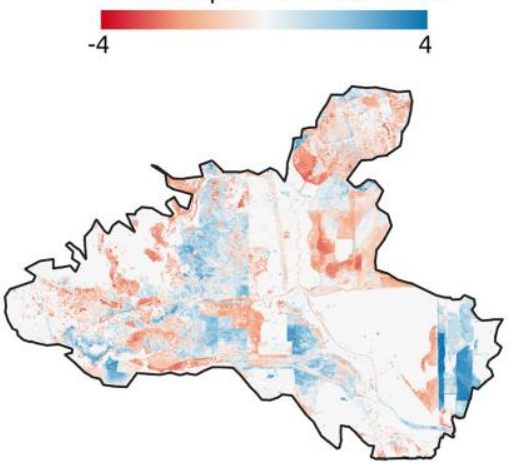

Mann Kendall Z score
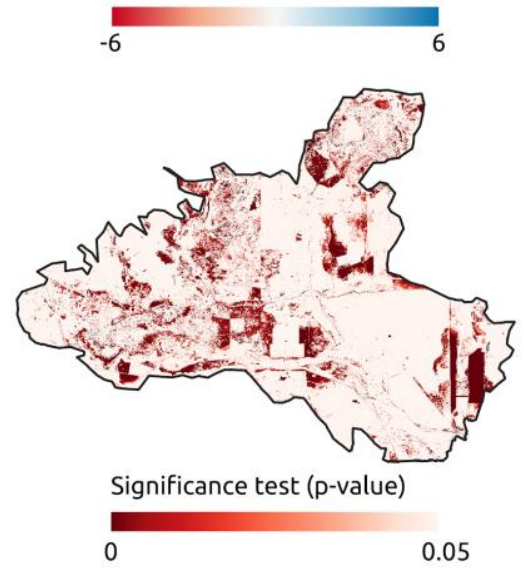

307 Figure 5. Surface water occurrence trends using the Man Kendall and the Sen's slope tests in the study 308 region.

310 Similar to the result found using MODIS data, the annual surface water occurrence time series indicates

311 strong evidence of $1,138 \mathrm{~km}^{2}$ experiencing significant changes in surface water occurrence, corresponding

312 to $7.39 \%$ of the study area extent, presenting a mean rate of change of $0.72 \%$ per year. From this, $704 \mathrm{~km}^{2}$

313 experience positive surface water occurrence trends at a mean rate of $1.94 \%$ per year. On the other hand, 
314 the remaining $433 \mathrm{~km}^{2}$ experience negative surface water occurrence trends at a rate of, on average, $1.25 \%$

315 per year. While the upstream areas present mostly negative trends, the opposite behaviour can be observed

316 in the downstream areas of the marshes, which seems to be affected by artificial hydraulic modifications.

317 This change in the natural surface water pattern needs to be studied to reach to further conclusions about

318 the effect on the ecosystems at various localities.

319 The most obvious change in water bodies (Figure 6) was due to disappearance/reappearance of water (as a 320 natural seasonal process) and due to drainage and reflooding periods (including human intervention). 321 However, a significant loss $\left(533 \mathrm{~km}^{2}\right.$; Supplementary 4) of permanent water extent can be observed, mostly 322 in the eastern part of the marshlands. This significant loss was caused by the government building new 323 dams and drainage canals, especially in the Hammar and central marshes (Al-Chibayish), which led to 324 diversion of water from the marshes (Lawler, 2005). Large areas $\left(8,222 \mathrm{~km}^{2}\right)$ did not experience any change 325 since the 1980s. Whereas, new seasonal areas $\left(1,253 \mathrm{~km}^{2}\right)$ have appeared in the marshes, and this was 326 expected because of the government legislated restoration plans to restore Mesopotamia's marshlands (after 327 2003; effectively after 2005). 


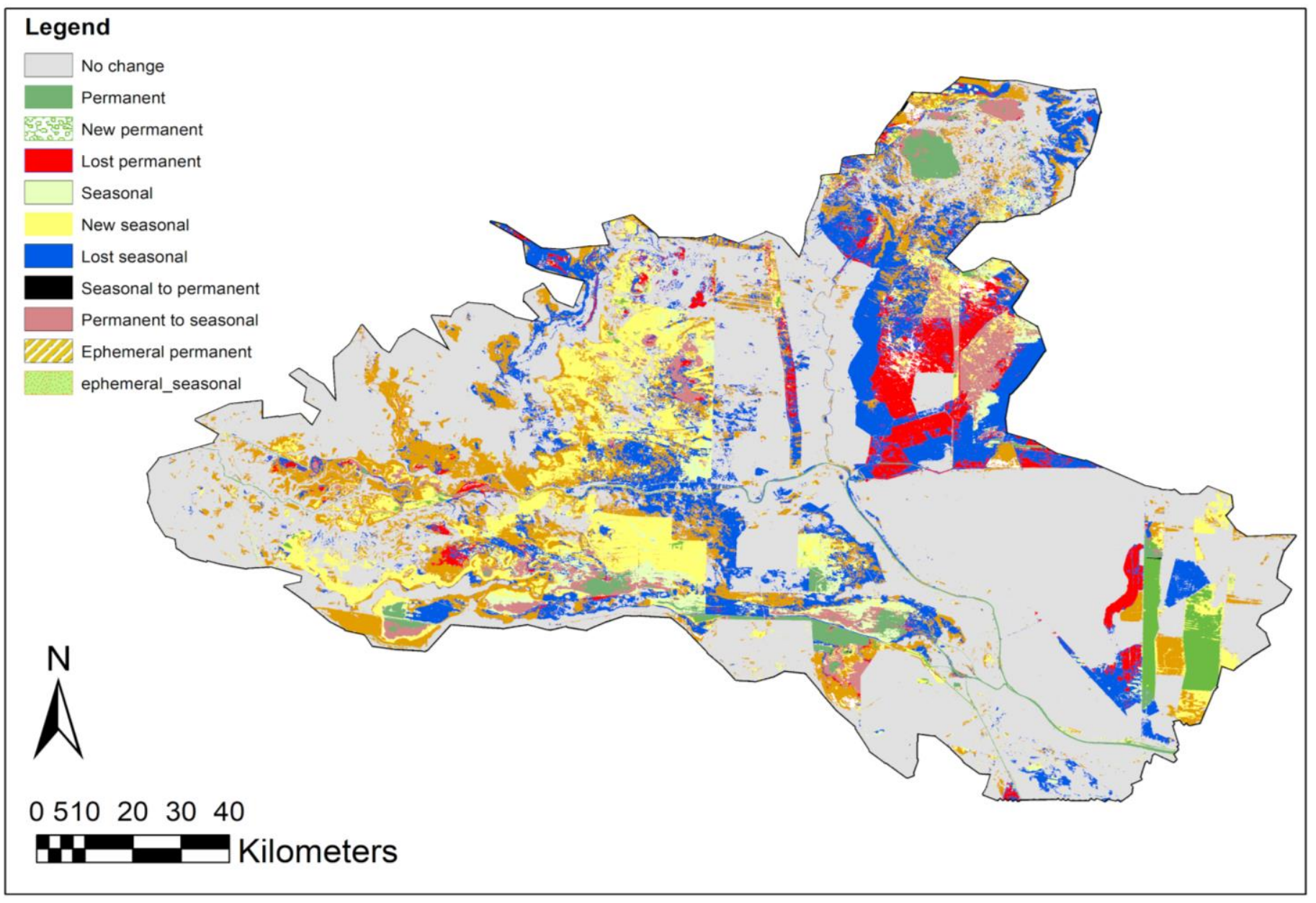

Figure 6. Transition map of water in the marshlands.

\section{Response of vegetation cover to drainage and reflooding periods}

333 Significant changes in the above-ground biomass have taken place during the study period. Figure 7 shows

334 that the vegetation cover was not affected by any stressors especially in the Central marsh for the periods 335 (1985-1990 and 1990-1995). However, the subsequent two periods (1995-2000 and 2000-2005) showed 336 that a massive reduction in the vegetation cover which subsequently caused the destruction of the ecosystem 337 in this marsh (Hashim et al. 2019). After 2003, a restoration plan (named "Restoring the Garden of Eden") 338 was implemented, which started effectively after 2005 as a scheduled reflooding program (Richardson and 339 Hussain 2006). The reflooding periods helped this marsh to recover slightly during the periods (2005-2010 and 2010-2015) (Albarakat et al. 2018). This helped most of the plant species to re-appear in this marsh 
341 (Hamdan et al. 2010). The last period (2015-2020) did not show any decline in the NDVI, meaning that 342 vegetation was not affected in this period.

343 The vegetation covers experienced successive loss of extent (Supplementary 3), which resulted from the 344 vanishing marshlands' extents. According to the statistics, bare soil and vegetation covers for the period 345 1985-1990 were about 8699.52 and $4487.95 \mathrm{~km}^{2}$, respectively. For the period 2000-2005, the vegetation 346 cover has lost its extent vastly to be about 1450.95, whereas bare soil extent increased to about 13376.48 $347 \mathrm{~km}^{2}$. After the start of the reflooding (2003) programmes, the area of the vegetation cover has noticeably 348 increased due to releasing water into these marshes to cover about $3921.24 \mathrm{~km}^{2}$. This has been accompanied 349 with an increase of the marshlands extent $\left(\sim 1928.75 \mathrm{~km}^{2}\right)$ for the period 2015-2020, whereas bare soil 350 extent reduced to about $9536.3 \mathrm{~km}^{2}$ and this was expected after the recovery of the marshlands. 


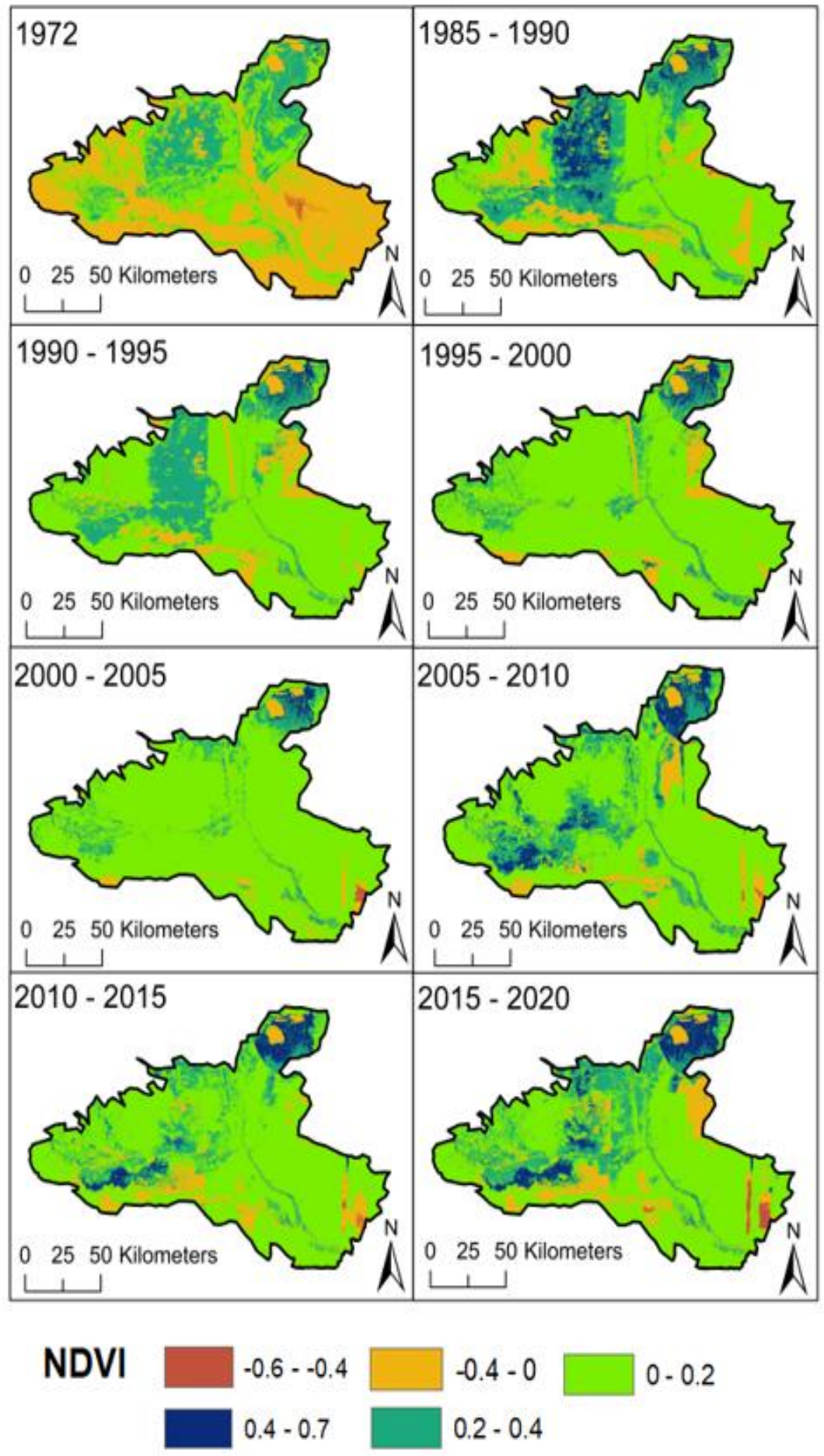

352 Figure 7. Mean NDVI over the study area. Each image is the mean NDVI for subsequent 5-year blocks 353 (except the NDVI from 1972, which was calculated as the NDVI in August 1972). 
Monitoring and investigating the spatio-temporal changes within the ancient Mesopotamian marshlands

357 was the main aim of this study. The best extent/availability of satellite imagery was employed from 1972 to 2020. Importance of these wetlands came from their essential functionality with their unique ecosystems in such semi-dry regions (Al-Hilli et al. 2009). Marshlands have overall been negatively impacted in the past on several temporal scales during this case study period with some clear up-and-down trends. On the spatial scales, significant changes have occurred to the marshland's areal extent from 1972 to 2020 . These changes could have happened due to several reasons: locally (including the bordering wars, and all its associated activities, as well as the governmental water control schemes); regionally on the catchment scale (including the upstream damming and construction on the main runoff streams); and globally (e.g., due to climate change and precipitation reductions). However, the analysis of the rainfall signal does not show evidence of long-term rainfall declines at the regional scale and even in wet years, the mashlands have

367 shown to decline. These human-induced environmental changes have significantly impacted the marshlands and the whole associated socio-economic aspects of the Mesopotamia region. Understanding these changes should ultimately provide a basis to make important decisions to address the health of the marsh system.

These changes and their causes answer this paper's fundamental question about the environmental catastrophe, the nature and reasons that were behind the rapid collapse of Mesopotamia's wetlands. These

372 wetlands have existed and developed for thousands of years and fed more humankind and all other species 373 than they do nowadays (Chatelard, G., 2009; Almukhtar, M.A.et al, 2016).

374 Even though lumped local rainfall shows some fluctuations over time, it does not show a long-term drying 375 trend. Likewise, periodic cycles of interannual variability might be observed, leading to wet and dry conditions, but these do not strongly relate to the marshland dynamic. This might imply two things: 1) local

377 rainfall has not played a major role in the flooding/drainage pattern; rather human intervention, over- 
379

380

381

382

383

384

385

386

387

388

389

390

391

392

or 2) rainfall trend patterns might be spatially variable, which might be obscured when aggregating rainfall at the catchment scale.

This study has confirmed the literature and shown that drainage and reflooding periods in the Mesopotamian wetlands led to disappearance and reappearance of water in the three major marshes - the Hammar Marsh, Huwaiza Marsh and the Central marshes (including Al-Chebaish Marsh). These periods of drainage and reflooding have caused a reduction in the wetland's extent by about $-15 \%$.

Although Table 1 of the land cover change analysis has shown an increasing trend in most of the surface cover classes, and particularly within the wetlands and water bodies, it was actually a reflection of the MODIS data length that started in a very dry period in 2000. In fact, this period post-2001 has turned into a slightly positive water occurrence (and its vegetation consequences), particularly after the restoration efforts in 2003. This was confirmed in Figure 2, which shows a clear decline in water occurrence from 1980s to 2001 and a slight increasing post 2000 (the MODIS launch date).

The most obvious change in water bodies (Figures 5 and 6) was due to the disappearance/reappearance of water due to the initial drainage and later reflooding periods; this was labelled the "lost seasonal". However, a significant loss $\left(533 \mathrm{~km}^{2}\right)$ in permanent water extent can be observed mostly in the eastern part of the marshlands. The eastern marshes are on/near the political border between Iraq and Iran, and the decline in water extent is partly related to the long border war that was concentrated within this area, as well as previous government policies of water diversion. Strong wet conditions have affected the region from mid 2018 to 2020 which has translated into a high surface water extent and a regain in marshland areas.

Furthermore, permanent water bodies delineated in the transition map (Figure 6) can also be contrasted with the seasonal and annual trends presented in Figure 5. However, it is clear from both sources of information that water infrastructure built downstream from the study region had a slight effect on the surrounding marshland areas, but does not translate into seasonal water changes. That should indicate, the key controlling factors may come from the upstream area (the catchment). 
403 The fluctuation from wet to dry periods is reflected by the significant NDVI dynamism, which indicates a

404 significant change in the vegetation cover. Figure 7 shows that there was a slight decrease in the NDVI values between 1972 and 1995 indicating that the vegetation cover was not much affected by any stressors especially in the Central marsh for the periods 1985-1990 and 1990-1995. However, the decline in the

407 NDVI trend showed sharp reductions in the vegetation cover in the periods 1995-2000 and 2000-2005,

408 which caused the destruction of the ecosystem in this marsh. Since 2005, the NDVI trend has gained some 409 positivity of vegetation occurrence as a reflection of the reflooding schemes, which have helped these 410 marshes to recover, even during moderate to severe drought conditions. Moreover, within the past five 411 years (2015-2020), the NDVI trends showed a significant increase, which indicates the success of the 412 restoration efforts and the occurrence of strong wet conditions. This has helped most of the plant species to 413 re-appear in these marshes (Hamdan et al. 2010).

414 However, the marshlands did not regain their original extent seen in the 1970s and 1980s despite the 415 releasing of water into them. This might indicate the need to understand that releasing water after long and 416 successive drought periods might not be enough to recover all the vanished plant species, nor the 417 ecosystem's biodiversity that was developed over thousands of years.

420 Landsat data allowed to monitor the water occurrence and surface cover' classes (and the dynamism of the

421 NDVI in particular) in an area size of $\sim 15,000 \mathrm{~km}^{2}$, showing an adequate resolution for this study; both 422 spatially (covering the whole study site) and temporally (1972-2020). The available MODIS dataset 423 allowed obtaining clear land cover change trends. However, its limited time coverage precludes it from 424 making conclusions before 2001. A significant overall decrease in the wetlands, including surface water 425 and the vegetation cover extents, with a major decline at around 2000 was observed. Since then, trends have 426 increased until 2020, helped in the last period for strong wet conditions. In other words, 2000 could be 
427 considered as a turning year in the environmental situation of the study site, which is supported by the 428 positive trends in water and marshland extents found with MODIS.

429 On the longer-term, significant wetlands reductions since 1972 can be explained by several environmental 430 and anthropogenic factors including: intensive local activities (e.g., the Iraqi government planned 431 "drainage" of the marshes plus the eight years of war); catchment modifications (especially water 432 diversion); and climate change. Some of these factors play a major role in the decline of marshland area 433 within the study site, including the drainage networks constructed by the government. Others, such as 434 rainfall, do not seem to have significantly changed over time. Thus, local human interventions, including 435 short-term agricultural development, seem to be the major causes affecting the marshland ecosystems. 436 Modern restoration has started a "slow" recovery of the marshes water extent but not to their original state.

437 Thus, it is essential for the future research to provide a greater understanding of the main influencing factors 438 from outside the Mesopotamian marshes with additional investigations to follow up some of the key-points 439 raised by this study, including: the need for a detailed study of the catchment area modifications and water 440 discharge fluctuations; local soil/water quality sampling and analysis; and ground truthing the whole 441 remotely sensed data and its analysis.

\section{Acknowledgements}

444 The first author would like to acknowledge Brian G. Jones and Martin Struck for reviewing and 445 commenting on the early version of the manuscript. The first author would like to acknowledge the 446 European Satellite Authority (ESA) for providing a Sentinel Hub for dataset and the Amazon Web Services 447 (AWS)-Machine Learning (ML) for their funding support for developing countries and for approving our 448 southern Mesopotamia wetlands monitoring project. 


\section{Funding}

452

This article did not receive any funding.

Conflicts of interest

454

Authors declare no conflict of interests

455

Ethics approval

456

Not applicable

457

\section{Consent to participate}

458

Not applicable

Consent for publication

460

Not applicable

Availability of data and material

All datasets used are publicly available.

\section{Code availability}

Not applicable

Authors' contributions

466

The original conception of the study was developed by A.K.M.A.N. All authors contributed to the study design. Material preparation, data collection and analysis were performed by I.F. and D.A.S. The first draft of the manuscript was written by all authors, who also read and approved the final manuscript. 
471 Abdulnaby W, Motaghi K, Shabanian E, Mahdi H, Al-Shukri H. Gök R (2020) Crustal structure of the 472 Mesopotamian Plain, east of Iraq. Tectonics, p.e2020TC006225.

473 Abed JM (2007) Status of water birds in restored southern Iraqi marshes. Marsh Bulletin, 2(1):64-79.

474 Abusch T (2020) Witches and Demons in Ancient Mesopotamia. In Further Studies on Mesopotamian 475 Witchcraft Beliefs and Literature (pp. 3-18). Brill. DOI: https://doi.org/10.1163/9789004421912_002

477 478 479 480 481 482 483 484 485 486 487 488 489 490

Al-Ansari N, Knutsson S, Ali A (2012) Restoring the Garden of Eden, Iraq. Journal of Earth Sciences and Geotechnical Engineering 2(1):53-88.

Albarakat R, Lakshmi V, Tucker CJ (2018) Using satellite remote sensing to study the impact of climate and anthropogenic changes in the Mesopotamian Marshlands, Iraq. Remote Sensing 10(10):1524. https://doi.org/10.3390/rs10101524.

Al-Hilli MR, Warner BG, Asada T, Douabul A (2009) An assessment of vegetation and environmental controls in the 1970s of the Mesopotamian wetlands of southern Iraq. Wetlands Ecology and Management 17(3):207-223.

Al-Kenzawi M, Hassan F, Al-Mayah A (2012) The distribution of Ceratophyllum demersum L. in relation to environmental. Marsh Bulletin 7:137-149.

Allan JA (2012) The Middle East Water Question: Hydropolitics and the Global Economy, London. ISBN 1860648134.

Al-Nasrawi AKM, Hamylton SM, Jones BG (2018). An assessment of anthropogenic and climatic stressors on estuaries using a spatio-temporal GIS-modelling approach for sustainability: Towamba estuary, southeastern Australia. Environmental Monitoring and Assessment 190(7): 1-26.

Al-Nasrawi AK (2018) Estuarine geomorphodynamic assessment of environmental change and stressor impacts: a geographic information systems and remote sensing (geoinformatics) modelling 

of Wollongong. Australia.

496

497

498

499

500

501

502

503

504

505

506

507

508

509

510

511

512

513

514

515

516

Al-Nasrawi AK, Jones BG, Alyazichi YM, Hamylton SM, Jameel MT, Hammadi AF (2016) Civil-GIS incorporated approach for water resource management in a developed catchment for urbangeomorphic sustainability: Tallowa Dam, southeastern Australia. International Soil and Water Conservation Research 4(4):304-313.

Almukhtar, M.A., Jasim, W. and Mutlak, F., 2016. Reproductive Biology of Hilsa Shad Tenualosa ilisha (Teleostei: Clupeidae) During Spawning Migration in the Shatt Al Arab River and Southern Al Hammar Marsh, Basra, Iraq. Journal of Fisheries and Aquatic Science, 11(1), p.43. DOI: 10.3923/jfas.2016.

Al-Zaidy KJ, Parisi G, Abed SA, Salim MA (2019) Classification of the key functional diversity of the marshes of southern Iraq Marshes. In Journal of Physics: Conference Series 1294 (7): 072021. IOP Publishing.

Banister KE (1980) The fishes of the Tigris and Euphrates Rivers. In Euphrates and Tigris, Mesopotamian Ecology and Destiny. vol 38. (pp. 95-108). Springer, Dordrecht. https://doi.org/10.1007/978-94$\underline{009-9171-2 \_9}$

Bayazit M, Önöz B (2007) To prewhiten or not to prewhiten in trend analysis? Hydrological Sciences Journal 52(4):611-624, DOI: 10.1623/hysj.52.4.611

Brauer G, Smith FH (2020) Continuity or Replacement: Controversies in Homo sapiens Evolution. CRC Press. Rotterdam, Netherlands.

Chatelard, G., 2009. Migration from Iraq between the Gulf and the Iraq wars (190-2003): Historical and sociospatial dimensions. Accessed on 26th January, 2021. https://halshs.archives-ouvertes.fr/halshs00364961 
Chew SC (1999) Ecological relations and the decline of civilizations in the Bronze Age world system: Mesopotamia and Harappa 2500-1700 BC. In: Goldfrank WL et al. (eds) Ecology and the WorldSystem. Greenwood publishing group, Ing. London. p.265.

Davidson NC, Dinesen L, Fennessy S, Finlayson CM, Grillas P, et al. (2019) A review of the adequacy of reporting to the Ramsar Convention on change in the ecological character of wetlands. Marine and Freshwater Research 71(1):117-126.

DeFries RS, Townshend JR (1994) NDVI-derived land cover classifications at a global scale. International Journal of Remote Sensing 15(17):3567-86.

Faiella G (2006) The Technology of Mesopotamia. Rosen Publishing Group, New York.

Foga S, Scaramuzza PL, Guo S, Zhu Z, Dilley Jr RD, et al. (2017) Cloud detection algorithm comparison and validation for operational Landsat data products. Remote Sensing of Environment 194:379-390.

Frankfort H (1950) Town planning in ancient Mesopotamia. The Town Planning Review 21(2):99-115.

Fuentes I, van Ogtrop F, Vervoort RW (2020) Long-term surface water trends and relationship with open water evaporation losses in the Namoi catchment, Australia. Journal of Hydrology 584:124714.

George A (2002) The Epic of Gilgamesh: the Babylonian Epic Poem and Other Texts in Akkadian and Sumerian. Penguin, New York.

Gorelick N, Hancher M, Dixon M, Ilyushchenko S, Thau D, et al., (2017) Google Earth Engine: planetaryscale geospatial analysis for everyone. Remote Sensing of Environment 202:18-27.

Guenang, G.M., Kamga, F.M., 2014. Computation of the Standardized Precipitation Index (SPI) and Its Use to Assess Drought Occurrences in Cameroon over Recent Decades. J. Appl. Meteor. Climatol. 53, 2310-2324. doi:10.1175/JAMCD-14-0032.1

Halverson GP, Hurtgen MT, Porter SM, Collins AS (2009) Neoproterozoic-Cambrian biogeochemical evolution. Developments in Precambrian Geology 16:351-365. 
541

542

543

544

545

546

547

548

549

550

551

552

553

554

555

556

557

558

559

560

561

562

563

564

Hamdan MA, Asada T, Hassan FM, Warner BG, Douabul A, et al. (2010) Vegetation response to reflooding in the Mesopotamian Wetlands, southern Iraq. Wetlands 30:177-188.

Hamilton C (2017) Defiant Earth: The Fate of Humans in the Anthropocene. John Wiley \& Sons. Cambridge, UK.

Hamman E, Van Geelen T, Akhtar-Khavari A (2019) Governance tools for the conservation of wetlands: the role of the Montreux Record under the Ramsar Convention. Marine and Freshwater Research 70(11):1493-1502.

Hamzeh S, Akbari E, Kakroodi A, Jeihooni M (2017). Investigation the dynamic response of the Anzali lagoon to sea-level changes using multi-sources remotely sensed data. The 38th Asian Conference on Remote Sensing. New Delhi.

Harley CD, Anderson KM, Demes KW, Jorve JP, Kordas RL, et al. (2012) Effects of climate change on global seaweed communities. Journal of Phycology 48(5):1064-1078.

Hashim BM, Sultan MA, Attyia MN, Al Maliki AA, Al-Ansari N (2019) Change detection and impact of climate changes to Iraqi southern marshes using Landsat 2 Mss, Landsat 8 Oli and sentinel 2 Msi data and Gis applications. Applied Sciences, 9(10):2016. https://doi.org/10.3390/app9102016.

Jotheri J, Altaweel M, Tuji A, Anma R, Pennington B, et al. (2018) Holocene fluvial and anthropogenic processes in the region of Uruk in southern Mesopotamia. Quaternary International 483:57-69.

Kohl PL, Lyonnet B (1826) By land and by sea: the circulation of materials and peoples, ca. 3500-1800 BC. BAR International Series 2008:29-42.

Kolbert E (2014) The sixth extinction: An unnatural history. A\&C Black.

Lawler A (2005) Reviving Iraq's wetlands. Science 307(5713):1186-1189. DOI: 10.1126/science.307.5713.1186

Lee RB, Daly RH, Daly R (1999) The Cambridge Encyclopedia of Hunters and Gatherers. Cambridge University Press. UK. 
Madani K (2014) Water management in Iran: what is causing the looming crisis? Journal of Environmental Studies and Sciences 4(4):315-328.

Maisels CK (2001) Early Civilizations of the Old World: the Formative Histories of Egypt, the Levant, Mesopotamia, India and China. Psychology Press. New York, USA.

Maltby E, Acreman MC (2011) Ecosystem services of wetlands: pathfinder for a new paradigm. Hydrological Sciences Journal 56(8):1341-1359.

McNally A, Arsenault K, Kumar S, Shukla S, Peterson P, et al. (2017) A land data assimilation system for sub-Saharan Africa food and water security applications. Scientific Data 4(1):1-19.

Meyer S (1959) The Neolithic revolution. Paléorient, 10, pp.2-1984. NY, USA.

Mitsch W, Gosselink J (1993) Wetlands 2nd edition, Van Nostrand Reinhold. New York.

Naddafi R, Abdoli A, Hassanzadeh Kiabi B, Mojazi Amiri B, Karami M (2005) Age, growth and reproduction of the Caspian roach (Rutilus rutilus caspicus) in the Anzali and Gomishan wetlands, North Iran. Journal of Applied Ichthyology 21(6):492-497.

Najafi A, Vatanfada J (2011) Environmental challenges in trans-boundary waters, case study: Hamoon Hirmand Wetland (Iran and Afghanistan). International Journal of Water Resources and Arid Environments 1(1):16-24.

O’Regan G (2008) Early Civilisations. In A Brief History of Computing (pp. 1-25). Springer, London.

Pekel JF, Cottam A, Gorelick N, Belward A (2016) High-resolution mapping of global surface water and its long-term changes. Nature 540:418-422.

Pollock S, Susan P (1999). Ancient Mesopotamia (Vol. 1). Cambridge University Press.

Potts DT (1997) Mesopotamian Civilization: the Material Foundations. Cornell University Press. NY, USA.

Purves D, Scharlemann JP, Harfoot M, Newbold T, Tittensor DP, Hutton J, Emmott S (2013) Time to model all life on Earth. Nature 493(7432):295-297. 
Putong JKM (2013) Digos: The Gate City of the South (1949-2013). Doctoral dissertation, Mindanao State University, Marawi City, Philippines.

Richardson CJ, Hussain NA (2006) Restoring the Garden of Eden: an ecological assessment of the marshes of Iraq. BioScience 56(6):477-489.

Richardson CJ, Reiss P, Hussain NA, Alwash AJ, Pool DJ (2005) The restoration potential of the Mesopotamian marshes of Iraq. Science 307(5713):1307-1311.

Robson D (2020) The civilisation that time forgot. New Scientist 245(3274):36-40. https://doi.org/10.1016/S0262-4079(20)30598-4

Senapati N, Stratonovitch P, Paul MJ, Semenov MA (2019) Drought tolerance during reproductive development is important for increasing wheat yield potential under climate change in Europe. Journal of Experimental Botany 70(9):2549-2560.

Shehab AT, Al-Ma'amar AF, Jabbar MFA (2010) Change detections in marsh areas, south Iraq, using remote sensing and GIS applications. Iraqi Bulletin of Geology and Mining 6:17-39.

Shubbar RM, Salman HH, Lee DI (2017) Characteristics of climate variation indices in Iraq using a statistical factor analysis. International Journal of Climatology 37(2):918-927.

Sissakian VK, Al-Ansari N, Adamo N, Zaiani MT, Abdullah M, Laue J (2020) Tectonics and neotectonics of the Mesopotamian Plain: a critical review. Earth Sciences and Geotechnical Engineering 10(4):57-86.

Sulla-Menashe D, Friedl MA (2018) User guide to collection 6 MODIS land cover (MCD12Q1 and MCD12C1) product. USGS: Reston, VA, USA, pp 1-18.

Trigger BG (1993) Early Civilizations: Ancient Egypt in Context. American University in Cairo Press. Cairo, Egypt.

Trigger BG (2003) Understanding Early Civilizations: a Comparative Study. Cambridge University Press. London. 
613 UNESCO-World Heritage Centre 2016. The Ahwar of Southern Iraq: Refuge of Biodiversity and the Relict 614 Landscape of the Mesopotamian Cities. United Nations. Available: https://whc.unesco.org/en/list/1481. Accessed 03 September 2020.

616 Zamani-Ahmadmahmoodi R, Esmaili-Sari A, Ghasempouri SM, Savabieasfahani M (2009) Mercury in 617 wetland birds of Iran and Iraq: contrasting resident Moorhen, Gallinula chloropus, and migratory 618 common teal, Anas crecca, life strategies. Bulletin of Environmental Contamination and Toxicology $619 \quad 82(4): 450$

620

621 


\section{Figures}

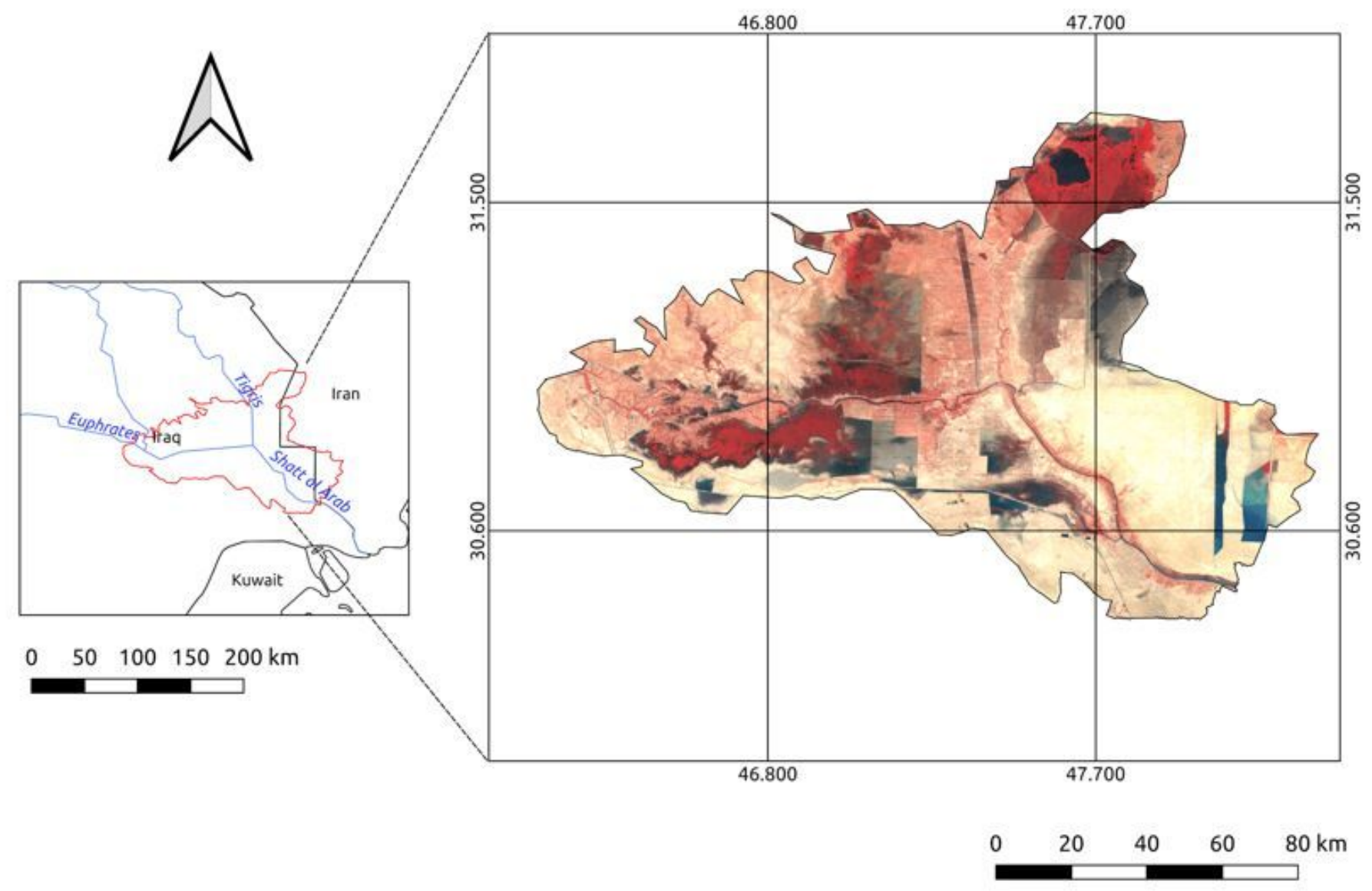

Figure 1

Spatial extent of Mesopotamian marshlands, as a false colour average composite of Landsat 8 images (2013-2020), in the study area located in southern Iraq and across the western Iranian border. Note: The designations employed and the presentation of the material on this map do not imply the expression of any opinion whatsoever on the part of Research Square concerning the legal status of any country, territory, city or area or of its authorities, or concerning the delimitation of its frontiers or boundaries. This map has been provided by the authors. 


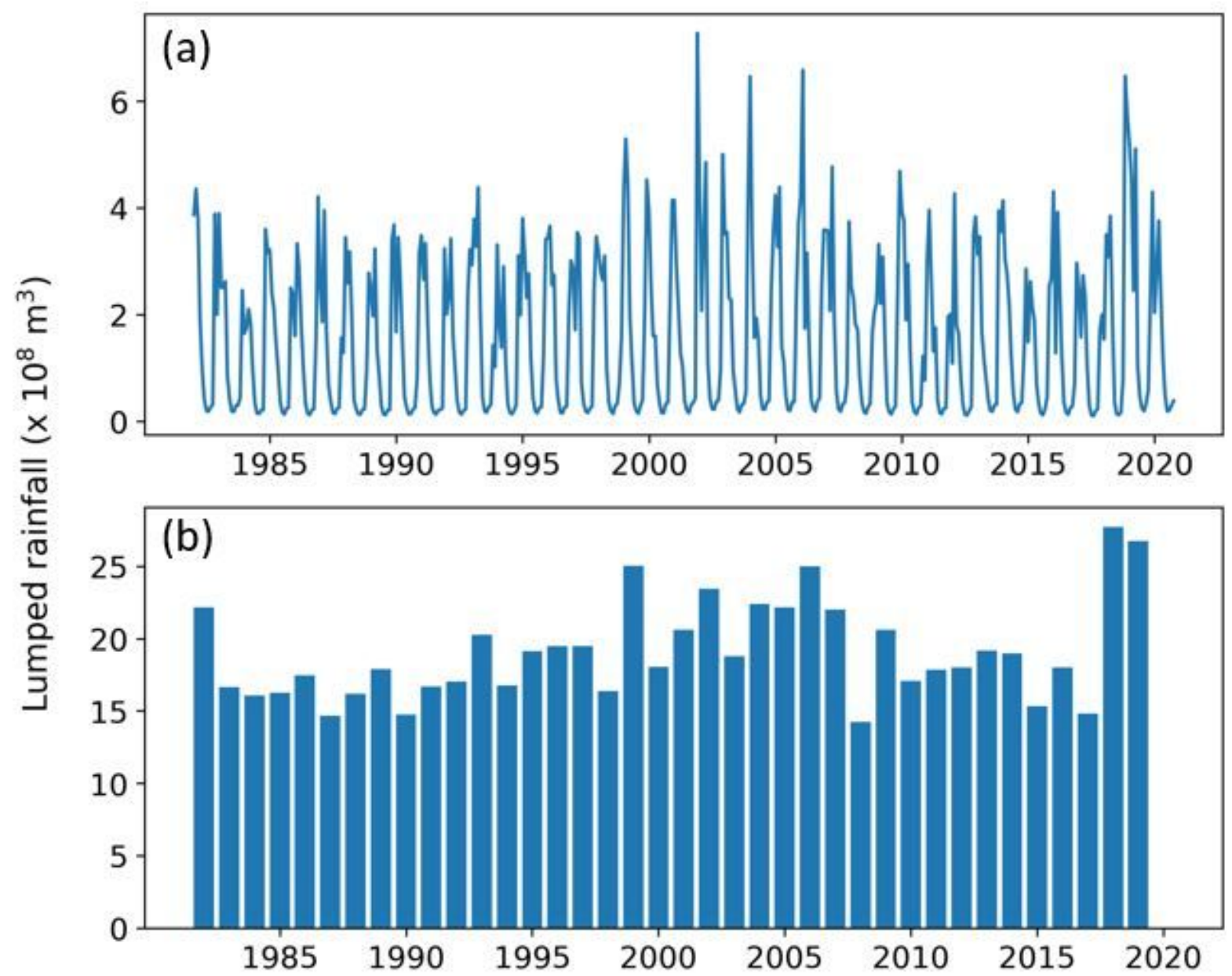

Figure 2

Lumped rainfall in the study region on (a) a monthly basis and (b) annually aggregated.
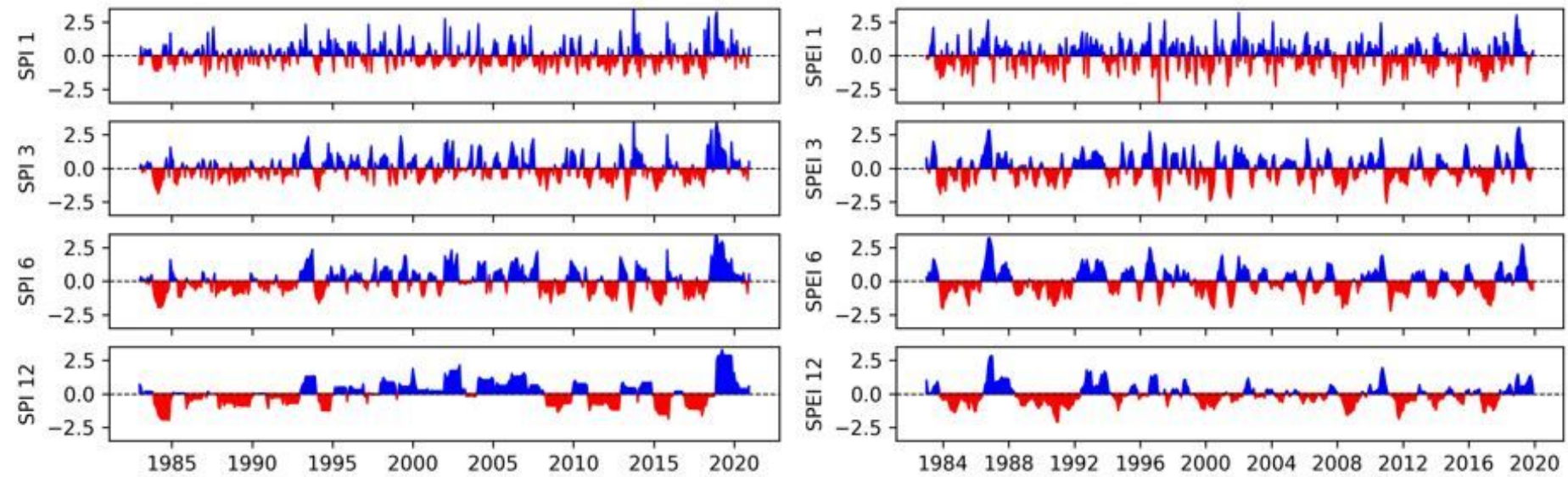
Figure 3

Average regional SPI (left) and SPEI (right) series using 1-, 3-, 6- and 12-month lags.
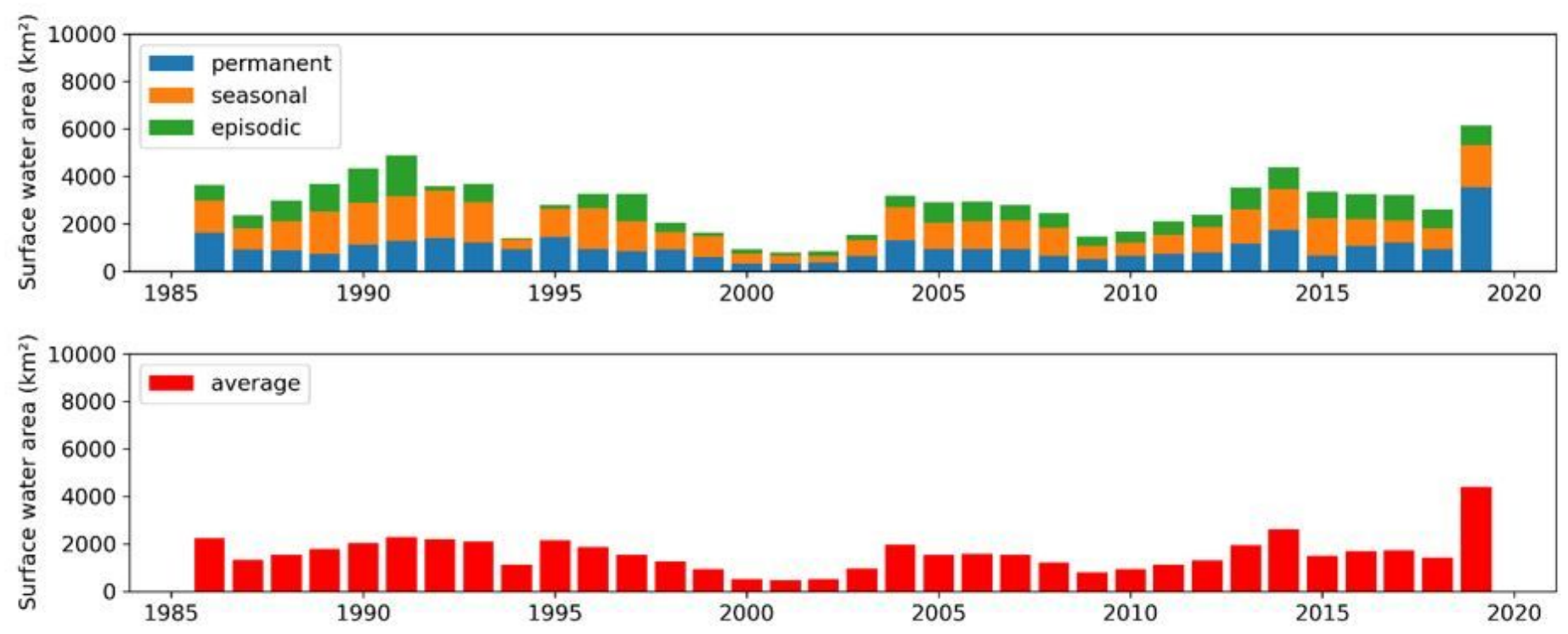

Figure 4

Annual time series of surface water fractions and average surface water extents in the study region. 


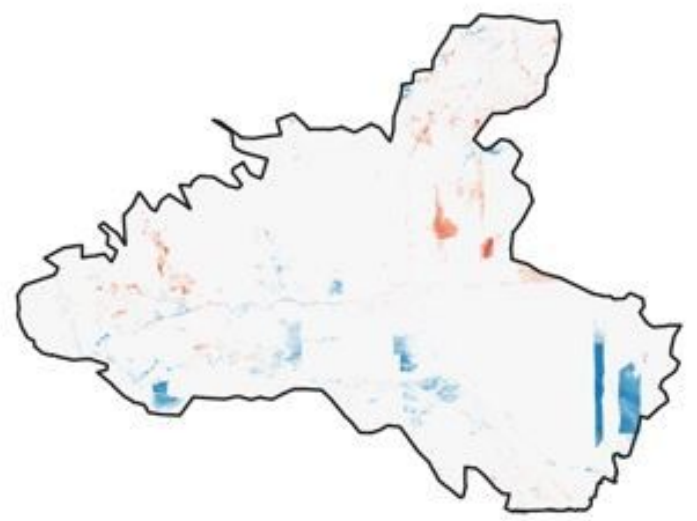

Sens's slope water occurrence
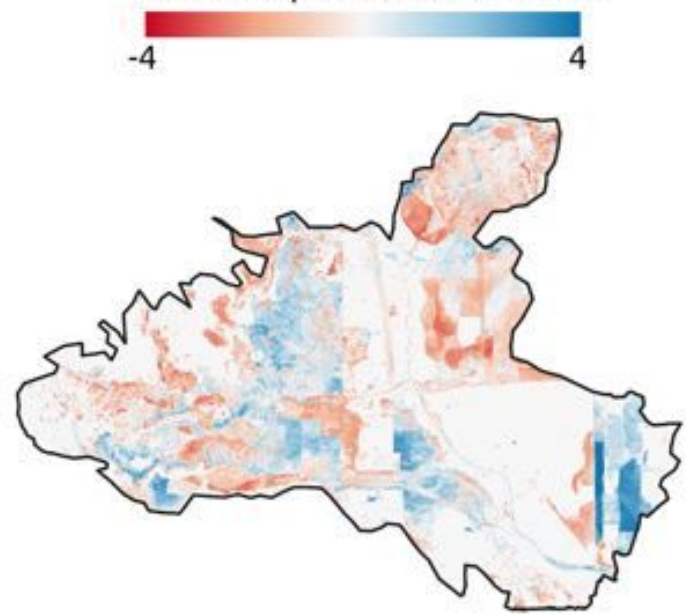

Mann Kendall Z score
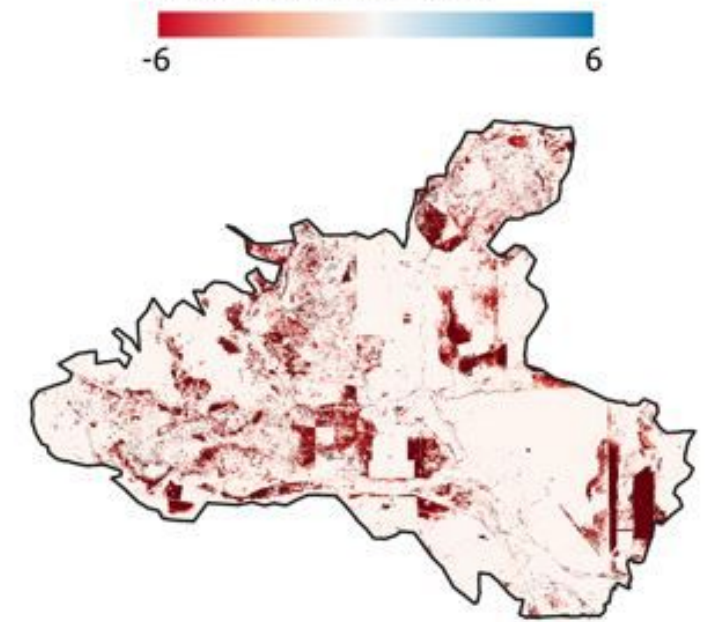

Significance test ( $p$-value)

0

0.05

\section{Figure 5}

Surface water occurrence trends using the Man Kendall and the Sen's slope tests in the study region. Note: The designations employed and the presentation of the material on this map do not imply the expression of any opinion whatsoever on the part of Research Square concerning the legal status of any country, territory, city or area or of its authorities, or concerning the delimitation of its frontiers or boundaries. This map has been provided by the authors. 


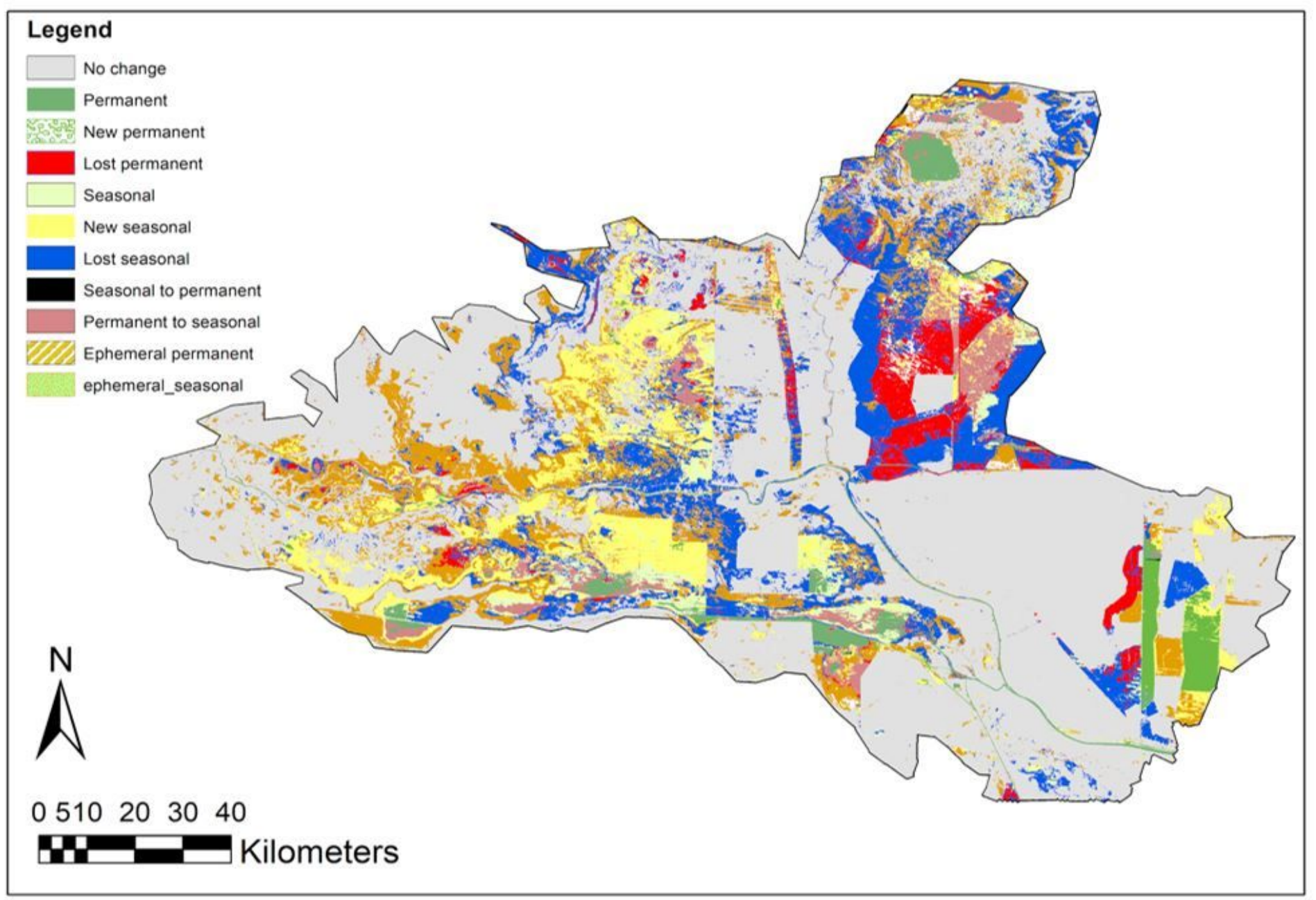

Figure 6

Transition map of water in the marshlands. Note: The designations employed and the presentation of the material on this map do not imply the expression of any opinion whatsoever on the part of Research Square concerning the legal status of any country, territory, city or area or of its authorities, or concerning the delimitation of its frontiers or boundaries. This map has been provided by the authors. 

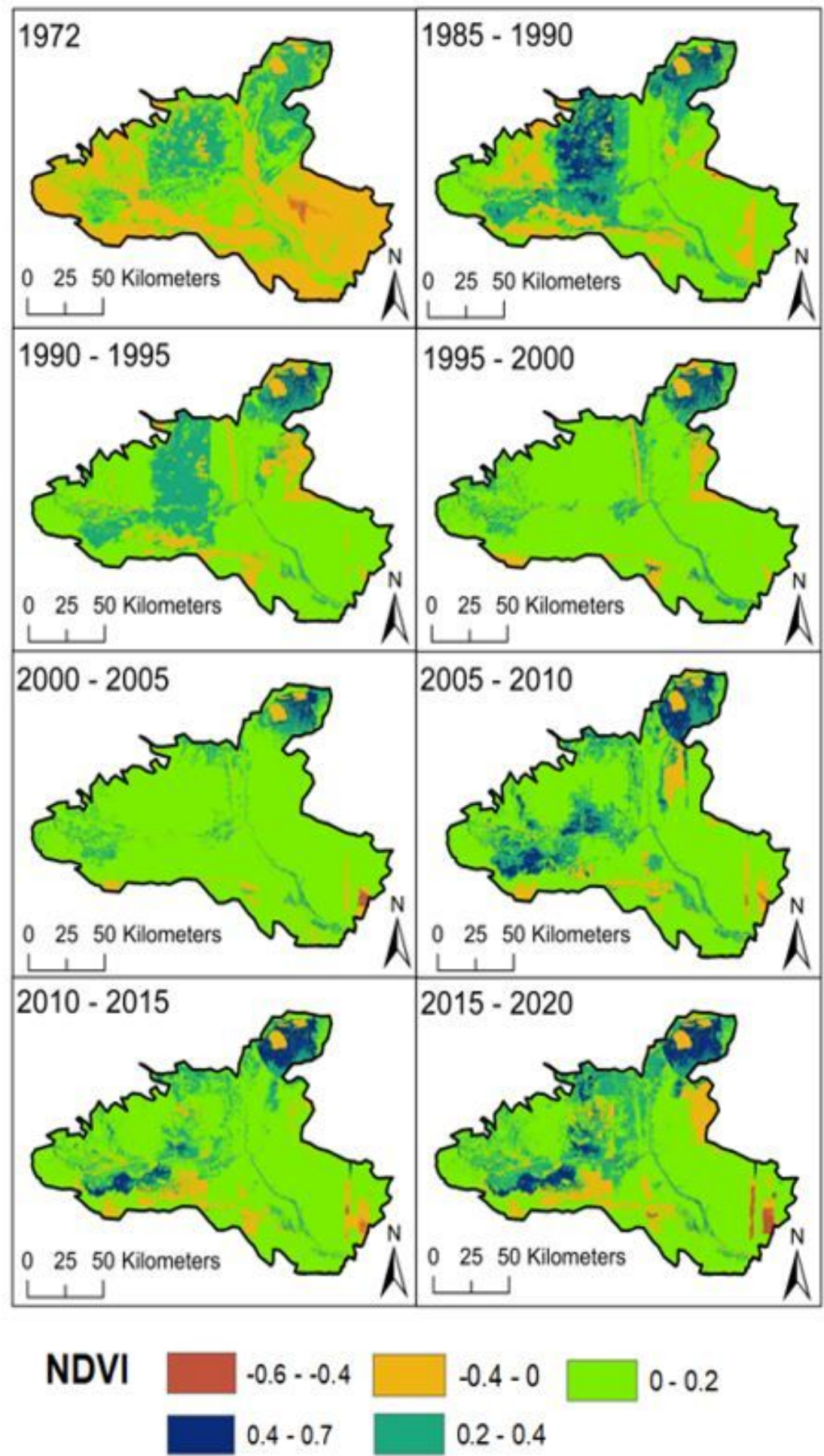

\section{Figure 7}

Mean NDVI over the study area. Each image is the mean NDVI for subsequent 5-year blocks (except the NDVI from 1972, which was calculated as the NDVI in August 1972). Note: The designations employed and the presentation of the material on this map do not imply the expression of any opinion whatsoever on the part of Research Square concerning the legal status of any country, territory, city or area or of its 
authorities, or concerning the delimitation of its frontiers or boundaries. This map has been provided by the authors.

\section{Supplementary Files}

This is a list of supplementary files associated with this preprint. Click to download.

- MesopotamiaSupplementaryWet.docx 